\title{
The Urgency of a Philosophical Approach in Islamic Education Learning in the Post Truth Era (Study at National-Based High Schools in Semarang Indonesia)
}

\author{
Agus Khunaifi \\ Universitas Islam Negeri Walisongo Semarang, Indonesia \\ \{agus_khunaifi@walisongo.ac.id\}
}

\begin{abstract}
Religion in the post truth era is the aspect most often manipulated. Religious manipulation does not only occur in the community but also in schools, including in the form of religious symbolization, exploitation of religion and politicization of religion. The purpose of this research is to observe the problem of Islamic religious learning in the post truth era and find a solution. This research was conducted in public schools in the city of Semarang in 2018. This type of research is a qualitative research field with a phenomenological approach. While the method of data collection by direct observation, interviews and documentation. The object of research in schools with nationalist ideology, both government and private. The results of the study found that the main components of religious learning include; Psychological characteristics of students, materials, learning methods and the environment have the potential to develop misunderstandings about Islam. The solution is that learning Islamic religion requires a philosophical approach to foster critical, logical and systematic attitudes of students in understanding religion.
\end{abstract}

Keywords: Philosophical Approuch; Islamic Education Learning; Post Truth Era

\section{Introduction}

The discourse of combining religion and philosophy has become a timeless and still interesting study. This is because both are sources of human virtue throughout the ages. The merger of the two has been carried out by philosophers and religious leaders for a long time. In particular, the amalgamation of religion and philosophy in Islam known as Islamic philosophy had reached its golden age. However, the amalgamation of the two in Islamic history gave rise to controversy among scholars. The controversy over the merging of religion and philosophy culminated in the era of Imam al-Ghozali (1058 AD-1111 AD) with his work tahafut al-Falasifah.[1] However, the discourse of merging the two was still ongoing after the era of Imam Ghozali with the birth of the character Suhrawardi (1154 AD-1191 AD) with his work of Isyroqiyah philosophy.[2] In short, the discourse of combining philosophy and religion among Muslims is still ongoing. 
The discourse of combining religion and philosophy in the post truth era is currently a very important theme. This is because in this era religion is the aspect that is most often misunderstood and misused. According to Yasir Halimi, religion is the most frequently abused aspect in Indonesia recently. The misuse of religion in this era includes the symbolization of religion, banal religion, exploitation of religion and politicization of religion.[3] Religion, which should have been a source of peace and peace, has turned into a source of violence and chaos. In other words, religion should be an enlightening way of life, but it is used as a tool for the benefit of humans. Currently, the phenomenon of misunderstanding and misuse of religion does not only occur in cyberspace but has penetrated in real life. Even misunderstandings and misuse of religion do not only occur in the community but also in schools. The many misunderstandings and abuses of religion in the post truth era have reopened this discourse.

The phenomenon of misunderstanding and abuse of religion in the school environment is currently a serious problem. This is because the school environment is a place of moral provision for future generations. If schools are not able to equip and protect the morale of their students, the life of a nation will be threatened. In short, religious problems in the school environment require urgent solutions.

Religious issues in the school environment in Indonesia are of course closely related to religious learning. This is because the national education system requires all formal education levels to carry out religious learning. Religious learning in educational institutions is a religious representation of the national character. However, at this time there is a fact that there is a gap between das sein and das solen in Islamic religious learning. Theoretically, learning Islam in school institutions should be able to increase the religiosity and morality of students. However, the reality is that currently there is an increase in sick religious patterns such as radical / extreme and a decrease in the morality of students.

According to Ratna Megawangi, the decline in morality is now a national problem. This is because the decline in morality occurs not only in the community but also in schools. According to him, the decline in morality that is most pronounced in big cities includes; violence, free sex, drugs, foul language and fighting parents.[4] Even Diah Rahmawati's research shows that the phenomenon of decreasing morality in the school environment has also occurred in small cities.[5] Furthermore, a decline in morality also occurred in both nationalist-based and religion-based schools.

On the other hand, there is the fact of the emergence of extreme and radical religious understanding in the school environment. According to Ma'arif's research, radicalism and extremism in the school environment are not fictional but real facts. According to him, educational institutions are one of the important instruments for the birth of radicalism and extremism.[6] The fact that there is radicalism in the school environment is revealed in Abdallah's research on the leaflets of violence in the name of religion. The leaflets of violence in the name of religion occurred in school communities in the Jombang, Jakarta and Bandung areas.[7] Furthermore, Zainiyati's research found a common thread between education and the emergence of radical movements in Indonesia. This study confirms that the educational environment is facing problems that require concrete solutions.

According to Daud Ali, an Islamic education expert, it is said that the birth of a sick religious person generally begins with an incorrect perspective or perspective. In general, the error in this perspective is influenced by two factors, namely external and internal. The first is the external factor, namely the strong influence of positiveistic rationalism due to the unstoppable pace of modernization and science and technology. This condition fosters a materialistic culture that results in life being partially understood, namely from a mere material dimension. Whereas the dimensions of human life are not single but spiritual and 
material. So that this factor encourages the birth of an incomplete perspective. The second internal factors, namely that there are some Muslims who have not been able to understand their teachings accurately, deeply and thoroughly and even tend to be wrong. Common mistakes that often occur in the lives of Muslims include: misunderstanding the scope of Islam, partially understanding Islam, misusing the Islamic study method.[8] Furthermore, according to Ary Ginanjar, mistakes in thinking are generally influenced by seven factors, namely prejudice, life principles, experiences, interests and priorities, viewpoints, comparisons and literature.[9]

Likewise, the opinion of Abdurahman Masud, a figure of Indonesian Islamic education, stated that this moral crisis originated from the inability of Indonesian Muslims to apply their religious values at a practical level. So that this moral crisis is not caused by people's understanding of Islam but because of a failure to apply religious teachings in real life. This is because the lives of Muslims are in a context that is constantly changing which requires constant innovation. So that the application of teachings in a dynamic context requires high intellectual and philosophical abilities.[10] Thus the role of reason in understanding and applying Islamic teachings appropriately is the main factor that cannot be ignored.

If a common thread is drawn, the main problem of Muslim diversity today is closely related to philosophical issues. Where deviant religious behavior generally originates from an inaccurate understanding. Because individually religious understanding will shape one's belief and at a later stage it will become a person's motive for action. Likewise, at the communal level, understanding the diversity of a society will affect its character and culture. Thus a philosophical approach is very logical in analyzing the problems of the nation and Islamic religious education in Indonesia today. Considering that the philosophical approach has the power to understand what is logical, systematic, comprehensive and profound.

Based on this background, the authors are interested in studying the problems of Islamic religious learning in school institutions in the post truth era. The theme of this research has been done before. However, the focus of the author's study is different from previous research which emphasizes more on proving the existence of religious manipulation in the form of radicalism and extremism in educational institutions. However, this study focuses more on efforts to find the root of the problem of Islamic religious learning and find a solution.

\section{Result and Discussion}

\subsection{Implications of the Post Truth Era in the Aspects of Education}

Post truth, which is defined as a time that goes beyond the truth, has a real social influence. The effect of post truth on social life can be understood from social mediation theory. According to Vergani, the events and discourses that develop on the internet have a significant effect on real life. He concluded that events online were the cause of events in reality. He gave an example that the war in Mindanao was a result of the narrative on social media.[11] Likewise Howard stated that events in real life often start from conversations in cyberspace. In short, the influence of post truth on social change originates from discourse on social media.

The characteristic of post truth that is most influential in social life is the change in the orientation of the public's view of the truth. Truth is no longer understood as the conformity of information with facts, but is adapted to individual emotions and beliefs.[12] So that today's society tends to accept invalid and even wrong information as long as it satisfies their emotions and beliefs. This post truth phenomenon is described in the Oxford dictionary as a 
condition in which facts are less influential in making public opinion than emotions and personal beliefs.[13] In other words, truth is no longer based on facts but on subjective perspectives, whether individuals, groups, politics or religions. In short, the post truth phenomenon is a phenomenon about changing the truth orientation from objective to subjective.

The most dominant influence of the post truth phenomenon in Indonesia is related to religion. According to Yasir, the post truth phenomenon in Indonesia is different from Western nations. According to him, in the West the phenomenon of post truth is dominated by political and scientific issues, while in Indonesia it is mostly dominated by religious issues.[3] The dominance of religious issues is evident on social media such as Facebook, Twitter, Instragam, YouTube and WhatsApp. In short, when we discuss the post truth phenomenon in Indonesia, in essence we are discussing religious problems. Thus the post truth phenomenon in the religious aspect becomes an interesting and important theme to study.

In particular, the influence of post truth in religious life can now be understood through the theory of religious mediation. According to this theory, religion is very much influenced by the media, even the functions of institutional and religious institutions have been taken over by the media. The media is not only a means of conveying religious messages but has taken over the role of producing certain religious understandings. Ironically, the media are not able to choose the right and wrong religious understanding but the group that uses the media the most will occupy the top position. In short, according to this theory, religion has the potential to be manipulated by certain interests in the post truth era.

The potential for religious manipulation in the post truth era is reinforced by hoax facts that are very high in Indonesia. According to data from the Ministry of Communication and Information, there are around 800,000 sites in Indonesia that have been indicated as spreading false information. He explained that these sites were used to produce and spread hoax news to create anxiety and mutual suspicion in the community.[14] In other words, hoaxes in the post truht era are not ordinary lies but deliberate lies. in short, the existence of hoaxes is currently being deliberately produced by certain parties who have an interest

Hoax content is currently an incomprehensible phenomenon. Even educated circles can be trapped in hoaxes. This is because currently hoaxes are not merely false or false information. However, false information that is deliberately made for certain purposes. Even hoax is understood as the art of lying. According to Yasir, hoaxes currently manifest in many forms such as bullshit, propaganda, terror, hate speech and the like. In other words, hoaxes are highlevel lies made with a certain strategy.[3]

On the other hand, the increase in hoaxes in the community has not been matched by digital literacy skills. According to Baudrillard, this condition makes hoaxes easy for the public to accept because they have difficulty understanding the meaning and significance of excess information. According to him, the more information, the less meaning and the more information, the more directly destroy the meaning and significance.[15] In other words, truth orientation is no longer based on conformity between information and facts alone, but is more based on emotions and individual beliefs. In short, today's society tends to accept invalid and even wrong information as long as it satisfies their emotions and beliefs.

According to Yasir, the crisis of truth in the religious and moral aspects of Indonesia is not a mere fabrication. According to him, there are strong facts that show that the post truth phenomenon in Indonesia online is dominated by religious issues and religious figures.[3] The truth crisis in the religious aspect in Indonesia includes the exploitation of religion for certain interests, religious symbolization, propaganda, hoaxes, intolerant content and even bullshit. According to Yasir, this phenomenon has the potential to cause radical, extreme and intolerant 
religious behavior that can lead to a crisis of religious and moral values. He further stated that if this phenomenon is not anticipated it will very easily spread into problems that can lead to divisions and civil wars that weaken national resilience.[3] Thus, the post truth phenomenon in Indonesia that is most worrying about irregularities is related to the religious aspect.

The crisis of truth in the religious and moral aspects is a serious problem. This is because the crisis of truth in the religious aspect involves a sensitive element of belief. Remembering beliefs in a religion often involves more emotional aspects. So that in religious matters, it requires the support of the truth in order to avoid false beliefs. The mistake of building belief in the aspect of religion will have a big impact on one's behavior. A person whose belief structure is wrong will commit a crime without feeling guilty. In other words, a person will feel right to commit a crime because he feels he has practiced religious teachings. In addition, the crisis of truth in the aspect of religion is very difficult to change. Remembering the truth in the realm of religion involves absolute beliefs. When someone has believed the truth as absolute truth it is very difficult to change. Thus, the crisis of truth in the religious aspect in the post truth era cannot be underestimated.

Furthermore, social changes in the post truth era automatically come into contact with educational institutions. This is because educational institutions in particular have a relationship with social and cultural change. Even according to H.A.R. Tilaar, educational institutions are one of the channels for the implementation of change. In other words, educational institutions become institutions that are in direct contact with social change either by supporting or counteracting.[16] Furthermore, according to Tilaar, the characteristic of quality education is education that is most sensitive to the demands of the times. The goal is that the world of education is not abandoned by society, because it can always answer the needs of society itself. In short, educational institutions in the posth truh era have become important instruments in counteracting or supporting its implications.

\subsection{History of Islamic Religious Education Lessons in National-Based Schools}

The history of Islamic religious studies in nationalist schools can be traced from the dynamics of Islamic education institutions in Indonesia. The dynamic of educational institutions that is striking is the birth of three formal educational institutions, namely pesantren, madrasah and schools.[17] According to Zamakhsari Dhofier, the dynamics of this formal education institution originated from the characteristics of the pesantren as the oldest educational institution in Indonesia which is very dynamic. The dynamics of this pesantren is shown by the birth of the salaf (traditional) and kholaf (modern) pesantren. According to him, the dynamic characteristics of this pesantren are what encourage further development of educational institutions.[18] The actual dynamic is the development of school education institutions based on ideology, namely religion and nationality. This dynamic will continue in line with the demands of the times.

The dynamics of educational institutions in Indonesia, when traced to the roots of their thoughts, cannot be separated from the spirit of renewing Islamic education itself. The majority of Muslim reformers believe that the truth of Islamic teachings is absolute and according to the demands of the times. This belief is the main reference for Muslim thinkers in responding to changing times. According to Zuhairini,[19] the renewal patterns of Islamic education can be classified into three types. First, the pattern of renewal of Islamic education which is oriented towards the modern education pattern in Europe. This group is of the view that the source of the strength and welfare of life that the West gets is the result of the development of science and technology. Meanwhile, science and technology are the 
development of Islamic teachings and culture. On the basis of this logic, this group argues that to restore the glory of Islam the most possible is to imitate the pattern of Western education. Second, the pattern of renewal of Islamic education which is oriented towards the purification of Islamic teachings. This group is of the view that Islam is a perfect religion that has complete knowledge. In other words, the source of progress and glory of Muslims is the teachings of Islam itself, so it must return to Islamic teachings. This renewal pattern was developed by Muhammad bin Abdul Wahab, followed by Jamaluddin al-Afgani. The three patterns of educational renewal are oriented towards nationalism. This pattern coincides with the modern pattern of life that develops in the West. This group tries to improve the lives of Muslims by paying attention to the situation and objective conditions of Muslims. These efforts are not only taken from Western culture, but also from the nation's cultural heritage. Likewise, education that is oriented towards nationalism is education in accordance with Islamic teachings. Education based on nationalism is understood as a historical necessity.

The demands of nationalism grew together with the development of modern life patterns based on Western philosophy. Modern society holds that the most humanist ties and unity are based on geographic areas. This view then becomes a reference in all aspects of life including education. The existence of both of them has the same position, both formal juridical and socio-cultural. This is because both have historical roots in Indonesian society. According to historical records, the development of education in Indonesia went through five stages, namely: 1) before independence, at this stage education was based on the goal of spreading religion, starting from Hinduism, Buddhism, Islam, Catholicism and Christianity, 2) during the Dutch and Japanese colonial times. , education was more based on the interests of the colonialists at that time, 3) the period of struggle for independence, education was more based on the transformation of regional insight into the spirit of Indonesian nationhood, 4) the early days of independence began to look for forms of a national education system as an effort to defend Indonesia's independence and 5) at the time the new order of education was held to fill Indonesia's independence through development activities in various fields.[20]

The characteristics of national-based educational institutions include; First, the tendency is influenced by the flow of liberalism which is still strong in the Netherlands, where the government must be neutral in the field of teaching, meaning that it is not above a certain religious stream. Second, the tendency is influenced by language politics in the framework of cultural politics. Third, since the establishment of schools has been driven more by practical needs, related to jobs in various fields and vocations. Fourth, the tendency shows that there is a strong idea that indigenous schools are more rooted in their own cultural environment, so the language of instruction used is the respective regional language.[19]

The term national-based school actually appeared only after Indonesia's independence. In the field of education, the government has just attempted to elaborate the two education systems. To develop the two education systems, two departments were established, namely the Ministry of Religion (DEPAG) and the Ministry of Education and Culture (DEPDIKBUD). Where the development of religious education is handled by the Ministry of Religion and general education by the Ministry of Education and Culture. Departing from these two institutional management, there was a distinction between Islamic and National-Based schools in the community. Islamic-based schools are under the auspices of the Ministry of Religion and national-based schools under the auspices of the Ministry of Education and Culture.

Formally, the recognition of the existence of Islamic religious learning in national-based schools has existed since the beginning of independence and during the 1945 Old Order period. Furthermore, the existence of Islamic religious learning became stronger in December 1946 with the issuance of a joint regulation by the two Ministers of Religion and the Minister 
of Education and Teaching. Then these regulations became stronger along with regulations from the parliament in 1973-1978 and 1983. The position of Islamic students became more established when Law Number 2 of 1989 concerning the National Education System was issued. In addition to affirming the position of Islamic religious education in public schools, the law also accommodates the existence of religious education institutions. In the next development, the existence of Islamic religious education in the national education system was strengthened again in Law number 20 of 2003 concerning the national education system which made religious education a compulsory content, both at the primary and secondary education levels. The National Education System Law is a decision that is more advanced than previous regulations and laws, because this law guarantees every student in each education unit to receive religious education in accordance with their religion and is taught by educators of the same faith.

Thus, it can be concluded that Islamic religion lessons in national-based schools are a solution that brings together two different views between Muslims and the government. In short, Islamic religious lessons become an instrument that brings together Muslims and the government. Where the process goes through a long way through political and bureaucratic channels.

\subsection{Learning Islamic Religious Education in Nationalist-Based High Schools}

Nationalist-based schools are educational institutions in Indonesia that carry out relatively few religious studies. This is because this institution uses the concept of Western education. Western education is strictly oriented towards education and practical skills. Meanwhile, religious education is understood as a personal issue that is not taught in schools. This concept colors the academic climate as a whole. Students are conditioned to learn natural science and practical skills. In short, learning Islam in nationalist-based schools is not a top priority.

In particular, religious learning in this study is based on four main components of learning including; First, the psychological characteristics of students; In the four schools, in general, adolescents are around 15-18 years old. In general, the students in grade 1 are 15-16 years old, in grade 2 the range is 17-18 and in grade 3 they are 18-19 years old.[21] At this age it is known as the West with adolecerer and Arabic for murahaqah. In general, this period was marked by two rapid changes related to physical and non-physical.[22] This fast physical growth generally causes chaos and conflict in adolescents.

The chaos during the teenage transition period was also felt by Islamic religious teachers in the field. This chaos includes not participating in congregational prayers, smoking, like making excuses. However, according to them it is still a reasonable juvenile delinquency.[23][24] This view is in accordance with the concept of Islamic psychology in which this disorder does not need special handling. In contrast to the Western concept which tends to require serious handling. According to Western psychology this chaos is inherent in our times. This age period is known as the transition period. The transition period is understood by Western psychology as a period of transition from children to adults.[25] This period is marked by rapid fundamental changes in cognitive, emotional, social and achievement aspects.[26] In other terms, this period is known as a period of self-search which often creates self-conflict.[27] Thus, this period is always followed by the emergence of internal conflicts that require serious handling.

According to Islamic psychology, chaos and conflict at this time are only incidental, not inherent. So that not all teenagers always experience this chaos and conflict. The reason on which it is based is that everything that is alive undergoes regular and systematic 
development. This development occurs in every being continuously from the phase of birth to death. Likewise, adolescent growth is essentially regular and systematic. This is based on the following verse: Q.S. al-Qamar: 49, Q.S. as-Sajdah: 7, Q.S. at-Tiin: 4 and Q.S. al-Infithaar: 78 This view understands that the chaos that occurs is not a result of this phase but is due to a disorder or disease that exists in the adolescent himself.[28] Thus Islamic psychologists understand that this phase does not require special handling.

The salient characteristic at this age that is directly related to the world of education is the complete cognitive development. In this phase, adolescents have the ability to coordinate two kinds of cognitive abilities, either simultaneously (simultaneously) or sequentially. Learners are able to think to solve problems using basic assumptions that are relevant to the environment to which they respond. Meanwhile, with abstract capacity, students are able to learn abstract subject matter, such as religion, mathematics and others.[29] At this time, according to Az-Za'balawi, adolescents do not only understand all phenomena sensory, but are also able to understand up to a meaningful level.[22]

In particular, religious development in this phase is interested in universal relationships in the universe and the purpose of human life. Thus the maturity of reason in this phase encourages serious thinking about material nature, family relationships, social relationships, feelings and mental orientation in order to ensure the truth of the information that has been known in the previous phase. This interest also occurs in learning Islam in the field. According to Islamic religious teachers, students' interest in this lesson is about mystical, spiritual and the afterlife.[23] The pressing problems of adolescence and demanding interpretation are the problems of tawhid (tauhid rububiyah and tauhid uluhiyah), the purpose of human creation, the origin of its occurrence, the phases that are passed in the creation process, the problem of the resurrection of the apocalypse, the meeting in the Mahsyar field, hisab, shirath, heaven. , hell, angels, jinn, wisdom from the Shari'a, imposition of worship, and matters of religion and life. In other words, this phase is the most appropriate phase to introduce religious concepts with a logical line of thought.[22] This is because the introduction of a logical line of thought will become the basis for understanding at a later age. A strong and correct understanding at this phase will form the overall religious building.

Second, learning materials; This aspect of learning is sufficient to support the achievement of quality learning. This is based on the fact that Islamic religious studies have a strategic position. This strategic position in the regulatory aspect, namely Islamic religious lessons become compulsory lessons in schools that all students must follow.[30] This obligation is certainly a very important learning motivation amplifier for students. However, in reality this strategic position has not created a good academic climate for studying Islam. In practice, not all students are interested in learning religion from their self-awareness properly. In general, students follow Islamic religious learning with the motivation to fulfill the obligations of the curriculum.[31] Furthermore, specifically, the material of Islam at the high school level covers all the main teachings of Islam, namely faith, syari'ah, morals and Islamic history. However, regulations at this level emphasize the material of Islamic law. This is very logical because aspects of Islamic law are very important and fundamental for a Muslim. This material serves to equip students to have sufficient understanding in carrying out worship both vertically and horizontally.

However, on the other hand, the emphasis on Islamic law material in this school is quite risky. This is because the material of Islamic law is quite a lot and heavy which requires sufficient time and teacher competence. It was also confirmed by a religion teacher that learning was often ineffective because it pursued the target of completing the material in a limited time.[31] In addition, the characteristics of this material have the potential to foster 
rigid religious understanding. This is due to the material characteristics of Islamic law regarding the limited choice between halal and haram. In short, learning in this school requires good management.[32]

Third, learning methods; Based on field observations, at least the methods currently used are lectures, discussions and other active methods. In this digital era, the most prominent thing is the use of internet networks in religious learning. This learning method is quite effective because students can learn not only through books but through the unlimited internet. However, Islamic teachers in the field admit that this learning method requires good guidance. According to one teacher, it is not uncommon for content retrieval from the internet to come from unclear sources that have the potential to negatively affect students' understanding[33].

Fourth, environmental aspects; the academic environment is a factor that is quite influential in learning. In general, the academic environment in the field is quite conducive and relatively comfortable for studying. However, in the post truth era, the academic environment in national-based schools has a high potential for religious manipulation. Among the factors that have the potential to generate religious manipulation are contradictory discourses including; Muslim vs non-Muslim religiosity, religious and nationalist ideology, as well as public and private institutions.[34] In short, this contradictory discourse in the post truth era, if it is not understood philosophically, has the potential to be manipulated.

\subsection{The Concept of a Philosophical Approach in Learning Islamic Religious Education}

The philosophical approach in learning Islam is based on the concept of a philosophical approach to the study of religion. The development of an approach is based on the reality of the common need for rationality in understanding both (philosophy and religion). According to Maurise Wiles, there are two facts that prove the need for rationality in both. First is the fact that reason plays a fundamental role in reflecting on religious experiences and beliefs in a religious tradition. The second is the fact that in describing the faith of the religious tradition one must use reason in producing logical arguments and in making justifiable claims.[35]

The main principle of a philosophical approach in religious studies is based on the view that philosophy is an activity of thought. So that the philosophical approach is understood as a process of continuous interaction and involvement by using reason in understanding religion so as to obtain rational arguments. In line with the character of philosophy, the nature of this approach is limited to trying to find rational arguments and explanations that do not arrive at concrete evidence. Until now, this type of approach that has been used in the scientific community can be classified into five types, namely: first, philosophy as a religion in principle, philosophy is used to discover and understand the ultimate reality in this universe. The highest reality (goodness, ultimate and God) is then used as a value system which is used as a guide in human life. Characters who use this type include Plato, Plotinus, Porphyry, Spinoza, Murdoch, Hartshorne and Griffen. Second, philosophy as a servant is basically the role of philosophy is in serving, supporting religious doctrines. As for figures belonging to this type, including Aquinas, John Lock, Basil Mitchell and Richard Swinburne. Third, philosophy as a space maker for faith, this type of approach seeks to explain religious concepts with reason and explain human dependence on revelation. Figures included in this genre include William Ockham, Immanuel Kant, Karl Bath and Alvin Plantiga. Fourth, philosophy as an analytical study of religion, the aim of this approach seeks to analyze and explain religious character and language, to find out how it works and the meaning it carries. In simple terms this approach seeks to understand human religious behavior regardless of the truth of his religious teachings. The figures included in this approach include; Antoni Flew, Paul Van 
Buren, RB Braith Waite and D.Z. Phillips. And fifth is philosophy as reasoning used in religious thought, this type of approach is basically a development of the fourth type, it just emphasizes more on aspects of the context. This approach seeks to observe the environment where a believer runs his life, identify the factors that influence it and see how that belief is expressed in doctrine and practice.[35]

If a conclusion is drawn based on the above classification, the concept used in this study can be positioned in the third type of approach. This approach seeks to understand Islamic teachings through thoughtful activities to gain rational understanding and arguments. In other words, ideas, ideas, methods and characteristics of philosophy are used to understand Islamic religious doctrines in order to obtain a more accurate understanding. In particular, the philosophical approach here is based on the prior belief about the truth of Islam or revelation as knowledge that is important for humans to understand and know their God. Thus this approach can be called philosophical theology.

The concept of a philosophical approach in Islamic religious learning is based on the seven basic principles of Islamic unity conveyed by Muhamad Abduh which was adapted by M. Quraish Shihab, namely: First, the unity of the universe, this principle explains that the universe was created by Allah SWT in a state, harmonious, balanced, and be in one control and control, through the laws which He established. Second, the unity of life, this principle explains that worldly life is one with heavenly life. The success or failure of the ukhrawi life is determined by his worldly deeds. Third, the unity of knowledge, this principle explains that Islam does not recognize the separation of religious knowledge and general sciences, because everything comes from Allah SWT. Fourth, the unity of faith and reason, this principle explains that each is needed and has its own territory, so it must complement each other. Fifth, religious unity, this principle explains that all religions brought by the Prophets came from Allah SWT. Its main principles concerning faith, sharia and morals have remained the same from ancient times to the present. The six unions of the human personality, this principle explains that humans are created in the same components, namely the earth and the divine spirit. And seventh, the principle of the unity of the individual and society, this principle explains that individuals and society must support one another.[36]

In particular, the concept of a philosophical approach in Islamic religious learning is based on the argument that the ability to think using correct logic is very important in religion. According to Mehdi, correct logic becomes the basis for a person to acquire truth and wisdom.[37] Furthermore, the ability to use correct logic will help produce correct religious belief and practice as well. In other words, building true diversity cannot be started from doctrine but from prior understanding. Thus the concept of this philosophical approach is an attempt to reaffirm the importance of the role of reason in religion.

\section{Acknowledgment}

The author feels indebted to several parties who have contributed greatly to this article. For this reason, the author would like to thank profusely to; first LP2M UIN Walisongo which has funded this research because without financial assistance this research will be difficult, the two authors are also indebted to my lecturers including Prof. Abdurrahman Mas'ud, M.A.Prof. Fatah Syukur, M.Ag., Dr. Makhfud Junaidi, M.Ag. and Dr. Moh. Yasir Alimi, M.A. Dr. Mat Solikhin, M.Ag. who have been of great help and advice in this research. Third, of course the authors would like to thank the entire nationalist-based high school academic community in the city of Semarang who have provided important information related to this research because without their information this research would not have been possible. 


\section{Conclusion}

The post truth era has a big influence on the diversity of Indonesian society. The real influence is related to the aspect of negating the truth on the religious aspect. This implication can be seen from the many lies in the name of religion such as nonsense, symbolization of religion, politicization of religion and violence in the name of religion on social media. In addition, there is also the fact that this influence has reached real life with ill religious understanding such as radicalism and extremism. Even this influence also enters the educational environment. In short, at this time the negation of the truth in the aspect of religion is not only on the internet, but occurs in the truth.

The influence of the post truth era on the educational environment is a serious phenomenon. Because the educational environment is a place to transmit knowledge in a chain. In other words, the influence of the post-truth era in the educational environment will be conveyed from creating to generations. In short, this phenomenon is allowed to continue to convey heresy.

One way to prevent the implications of the post truth era in educational institutions in Indonesia is through learning religious education. The most logical strategy is a philosophical approach. This is because the concept of a philosophical approach is not using common sense and correct thinking in understanding religion. The purpose of the philosophical approach is for students to have a correct religious understanding. Because correct religious understanding will produce correct belief building and ultimately result in correct behavior. In short, the correct understanding of religion becomes the foundation for building religiousness as a whole. If the understanding is correct, then all religious structures will be correct and vice versa.

A philosophical approach to learning Islam in the post era has become a necessity. This is due to the post-truth era religious issues related to the weakening of common sense logic. When the role of common sense logic weakens, it makes sense to the post truth era situation logic. Thus, being religious in the post-truth era is not enough to have strong faith, but also must have a correct understanding.

\section{References}

[1] al-Ghazzali, “Al-Ghazali’s Tahafut Al-Falasifah,” 1958.

[2] “A New Terminus Ad Quem for 'Umar al-Suhrawardī’s Magnum Opus.," J. Am. Orient. Soc., vol. 128, no. 2, pp. 285-293, Jun. 2008.

[3] A. M. Yasir, "Mediatisasi Agama Post-Truth dan Ketahanan Nasional," Yogyakarta LKiS, 2018.

[4] R. Megawangi, "Pendidikan karakter solusi yang tepat untuk membangun bangsa," Jakarta Indones. Herit. Found., 2004.

[5] D. Rahmawati, "PENGARUH PEMBELAJARAN PENDIDIKAN AGAMA ISLAM (PAI) TERHADAP PERILAKU SOSIAL SISWA KELAS VIII SEKOLAH MENENGAH PERTAMA (SMP) NEGERI 1 CIAWIGEBANG KECAMATAN CIAWIGEBANG KABUPATEN KUNINGAN.” IAIN Syekh Nurjati Cirebon, 2015.

[6] S. Ma'arif, L. C. Sebastian, and S. Sholihan, "A Soft Approach to Counter Radicalism: The Role of Traditional Islamic Education," Walisongo J. Penelit. Sos. Keagamaan, vol. 28, no. 1, pp. 1-28, 2020.

[7] A. Abdallah, "Exclusivism and Radicalism in Schools: State Policy and Educational 
Politics Revisited," Stud. Islam., vol. 23, no. 3, pp. 625-632, 2016.

[8] A. M. Daud, "Pendidikan Agama Islam," Jakarta PT. Raja, 1998.

[9] A. G. Agustian, "ESQ: Emotional Spiritual Quotient: Rahasia Sukses Membangun Kecerdasan Emosi dan Spiritual,” Jakarta Arga, 2001.

[10] A. Mas'ud, Menggagas Pendidikan Nondikotomik; Humanisme Religius Sebagai Paradigma Pendidikan Islam. Yogyakarta, 2002.

[11] M. Vergani, "Neojihadism and Muslim-Christian relations in the Mindanao resistance movement: a study of facebook digital narratives," Islam Christ. Relations, vol. 25, no. 3, pp. 357-372, 2014.

[12] M. Y. Alimi, "Theorizing Internet, Religion and Post Truth: an Article Review," Komunitas Int. J. Indones. Soc. Cult., vol. 11, no. 2, pp. 207-222, 2019.

[13] O. E. Dictionary, "Oxford english dictionary," Simpson, JA Weiner, ESC, 1989.

[14] Kebebasan Pers dan Pemberdayaan Masyarakat," Media, Jurnalisme dan Budaya Popular. Yogyakarta: Prodi Komunikasi UII dan UII Press, 2008.

[15] J. Baudrillard, Simulacra and simulation. University of Michigan press, 1994.

[16] H. A. R. Tilaar, Beberapa agenda reformasi pendidikan nasional dalam perspektif abad 21. IndonesiaTera, 1998.

[17] K. A. Steenbrink, "Pesantren, madrasah, sekolah: recente ontwikkelingen in Indonesisch Islamonderricht.” Meppel [Netherlands]: Krips Repro, 1974.

[18] Z. Dhofier, "The pesantren tradition: a study of the role of the kyai in the maintenance of the traditional ideology of Islam in Java," 2014.

[19] Z. Zuhairini, Sejarah Pendidikan Islam. Bumi Aksara, 2004.

[20] H. Akib, "Implementasi kebijakan: Apa, mengapa dan bagaimana," J. Ilm. Ilmu Adm. Publik, vol. 1, no. 1, pp. 1-11, 2012.

[21] "Observasi di sekolah di SMA X1, SMA X2 pada tanggal 22/08/2018 dan di SMA Y1, Y2 pada tanggal 23/08/2018."

[22] M. Sayyid, "Az-Za'balawi, Muhammad. 2007," Pendidik. Remaja antara Islam dan Ilmu Jiwa.

[23] "Hasil wawancara dengan guru Agama Islam SMA X2 dan SMA Y2 pada tanggal 23/09/2018."

[24] "Disimpulkan dari Wawancara dengan Kepala sekolah SMA Y1 dan SMA X1 pada tanggal 22/08/2018"

[25] E. P. Mulvey et al., "Theory and research on desistance from antisocial activity among serious adolescent offenders," Youth Violence Juv. Justice, vol. 2, no. 3, pp. 213-236, 2004.

[26] A. R. Piquero, J. Fagan, E. P. Mulvey, L. Steinberg, and C. Odgers, "Developmental trajectories of legal socialization among serious adolescent offenders," J. Crim. Law Criminol., vol. 96, no. 1, p. 267, 2005.

[27] R. M. Lerner and L. Steinberg, Handbook of adolescent psychology, volume 1: Individual bases of adolescent development, vol. 1. John Wiley \& Sons, 2009.

[28] R. Skinner, "Traditions, paradigms and basic concepts in Islamic psychology," J. Relig. Health, vol. 58, no. 4, pp. 1087-1094, 2019.

[29] H. B. Uno, “Orientasi baru dalam psikologi pembelajaran," Jakarta Bumi Aksara, 2006.

[30] H. H. P. Daulay, Sejarah Pertumbuhan \& Pembaruan Pendidikan Islam di Indonesia. Kencana, 2018.

[31] "Wawancara dengan guru agama Islam di SMA Y2 pada tanggal 25/08/2018."

[32] T. Hamami, "Pendidikan Agama Islam di Sekolah Umum sebagai Keharusan Sejarah," 
J. Pendidik. Agama Islam, vol. 1, no. 2, pp. 171-191, 2004.

[33] "Wawancari dengan guru SMA X1 pada tanggal 26/09/2018."

[34] "Disimpulkan dari observasi dan wawancara peserta didik di SMA X1 dan SMA Y1 pada tanggal 26/08/2018."

[35] R. Fisher, "Philosophical approaches," Approaches to study Relig., pp. 105-134, 2001.

[36] M. Q. Shihab, "Wawasan Al-Quran," Bandung: Mizan, 1996.

[37] M. H. Yazdi, Principles of Epistemology in Islamic Philosophy, The: Knowledge by Presence. Suny Press, 1992. 